\section{Literatuur en geneeskunde}

Meulenberg F, Van der Meer J, Oderwald JAK, redactie. Ziektebeelden. Essays over literatuur en geneeskunde. Utrecht: Lemma, 2002. 730 pagina's, € 49,50. ISBN 90-5931-094-2.

Ziektebeelden is een boek om op het nachtkastje te leggen. Ruim zevenhonderd pagina's verdeeld over een kleine zeventig essays, waarvan sommige ware juweeltjes zijn. Een boek om 's avonds laat nog even in te lezen en er dan nog wat over na te mijmeren. Zo'n boek dat je niet leest, maar in kleine stukjes tot je neemt.

De formule is eenvoudig. De redactie heeft een aantal auteurs - velen van hen werken in de Nederlandse gezondheidszorg - gevraagd om een essay te schrijven over een boek, gedicht, of novelle uit de nationale of internationale literatuur, dat raakt aan thema's rond ziekte en ziek-zijn, en hen op een of andere manier getroffen heeft. Het resultaat is op twee niveaus verrassend. In de eerste plaats vanwege de bundeling van al die bijdragen, waarmee in één klap de rijkdom van de literatuur als informatiebron en inspiratiebron voor artsen en andere hulpverleners zichtbaar wordt. Wat is er veel geschreven over ziektebeelden in de verzamelde literatuur en wat een wijsheid en humor leveren die publicaties op! Het boek bevat daarnaast een extra bonus. Veel van de auteurs kende ik van vergadertafels, congreszalen en uit de medische literatuur. In Ziektebeelden leer je ze van een heel andere kant kennen: door de keuze van het boek dat ze bespreken, door de invalshoek die ze daarbij kiezen, door de meerwaarde die ze af en toe in hun analyses en reflecties geven aan de teksten die ze onderhanden nemen.

De kwaliteit van de verschillende bijdragen is wisselend, maar doordat de redactie een heldere opdracht aan de auteurs heeft meegegeven zijn ze allemaal de moeite waard. Bovendien zit - zoals vaak in bundels als deze - de kwaliteit voor een belangrijk deel ook in het oog van de lezer. En als een stuk niet aanspreekt, ga je gewoon snel naar een ander, daar is het boek dik genoeg voor. Ikzelf heb ervan genoten, soms door het feest van de herkenning, als een van de auteurs iets opmerkt wat mijzelf ook al was opgevallen, soms ook juist door de verrassing wanneer een bekend boek door de invalshoek die bij de bespreking gekozen werd ineens een meerwaarde blijkt te hebben die mijzelf vroeger bij het lezen was ontgaan. Dat gold wat mij betreft in het bijzonder voor de kinderboeken die ik vroeger naïef heb gelezen en voorgelezen, maar mij nu meer hebben geleerd van ziektebeelden bij kinderen dan de resultaten van het vele vragenlijstonderzoek dat tegenwoordig over ons wordt uitgestort.

Ziektebeelden is een mooi voorbeeld hoe alfakennis inzichten kan opleveren die meer en anders zijn dan de traditionele bètamedische kennis. Het helpt de humane kant van de geneeskunde op het netvlies te houden. Daarom is het niet zomaar een goed boek voor op het nachtkastje; het zou ook daadwerkelijk op alle nachtkastjes van dokters moeten liggen!

J.M. Bensing

\section{Misvattingen uit cultuur en wetenschap}

Hans van Maanen. Encyclopedie van misvattingen Amsterdam: Boom, 2001. 297 pagina's, € 24,50 ISBN 90-5352-834-2.

Wetenschapsjournalist Hans van Maanen verzamelt al jaren misvattingen uit cultuur en wetenschap. Deze bundel - met lichtvoetige ironie tot 'encyclopedie' bestempeld - bevat ongeveer 600 algemene weetjes en stellingen die stuk voor stuk een misvatting blijken te zijn. Hij weerlegt en nuanceert stellingen uit kunst (Johnny Weismuller zei: 'Me Tarzan, you Jane.'), aardrijkskunde ('Mexico City is de hoofdstad van Mexico.'), gezondheid ('Handen wassen voor het eten!'), wetenschap ('De zon komt in het oosten op.'), geloof ('Eva at een appel') en biologie ('een worm kun je doormidden hakken'). De toon is ontnuchterend nuchter, als ik dit bijna-pleonasme mag gebruiken. Zo begint de weerlegging van de opvatting 'Een worm kun je zo doormid- den hakken' als volgt: 'Het kan wel, maar de worm overleeft het niet.'

Op het eerste gezicht denkt een lezer: 'Wat een leuke verzameling'. En hij begint grinnikend te bladeren en te snoepen. Maar dat tamelijk achteloze bladeren duurt niet lang. Lezen gaat steeds langzamer. Dan blijkt dat Van Maanen de lezer in drijfzand heeft gelokt. Want elk stukje dwingt de lezer tot het beantwoorden van op zijn minst drie vragen: 'Ken ik deze opvatting?' 'Besefte ik dat het een misvatting was?' 'Ben ik het eens met de weerlegging van de opvatting?'

Zo zet Van Maanen aan tot nadenken en brengt hij alle mogelijke emoties teweeg, van gêne ('Oei, ook ik huldig die misvatting.') via instemming ('Ja, dat wist ik, wat stom dat anderen dat nog steeds denken.') tot vreugde ('Volgens mij heeft Van Maanen het bij het verkeerde eind!'). Bij mij kwamen deze reacties respectievelijk op bij de stellingen 'Nederland werd op 5 mei 1945 bevrijd' (dat dacht ik namelijk ook), 'Eskimo's hebben twintig woorden voor sneeuw' (ah, de oude en achterhaalde SapirWhorff-hypothese) en 'De maag rammelt van de honger' (volgens mij is hier sprake van een metafoor - een brekend liefdeshart 'breekt' immers ook niet in tweeën). 'Onze hersenen lijken meer op een uitdragerij, vol met verstofte feiten en vastgeroeste meningen, met nooit weerlegde onzin en nimmer getoetste geruchten', zo schrijft hij in de inleiding. Dat is meteen zijn doel: morrelen aan het gemakzuchtig 'slikken' van kennis-van-horen-zeggen. Van Maanen is verre van een arrogant leermeester. Hij zoekt naar waarheid, maar 'de waarheid zullen wij wel nooit vinden, maar sommige opvattingen zijn minder onwaar dan andere.' En hij verzucht: 'De hersenen zijn geen haar beter dan het hart'.

Het is een verschrikkelijk leuk boek, waarmee ik bedoel dat het 'leuk' is én 'verschrikkelijk' omdat je er niet los van komt. Wat is prettiger dan het heftig eens of oneens te zijn met een auteur? Derhalve, lees het boek, nee, spel het boek en reageer op zijn mailadres dat ik hier verklap (het adres staat niet in het 